Tropical Journal of Pharmaceutical Research September 2016; 15 (9): 1859-1863

ISSN: $1596-5996$ (print); 1596-9827 (electronic)

(C) Pharmacotherapy Group, Faculty of Pharmacy, University of Benin, Benin City, 300001 Nigeria.

All rights reserved.

Available online at http://www.tjpr.org

Original Research Article

http://dx.doi.org/10.4314/tjpr.v15i9.7

\title{
Antipyretic, analgesic and anti-inflammatory activities of methanol extract of root bark of Acacia jacquemontii Benth (Fabaceae) in experimental animals
}

\author{
Khuram Ashfaq*, Bashir A Choudhary, Muhammad Uzair, Sajid N Hussain, \\ Muhammad A Ghaffari, Wajid Sarwar and Majid Manzoor \\ Faculty of Pharmacy, Bahauddin Zakaryia University, Multan, Pakistan
}

*For correspondence: Email: Khuram_ashfaq120@yahoo.com; Tel: +920619210153

Received: 6 May 2016

Revised accepted: 23 August 2016

\begin{abstract}
Purpose: To investigate the ethnomedicinal claims regarding the use of Acacia jacquemontii Benth. (Fabaceae) in fever, pain and inflammation.

Methods: The methanol root bark extract (AJRBM) of the plant was used in the studies. Preliminary phytochemical screening of the extract was carried out according to established methods. Analgesic, anti-inflammatory and antipyretic activities were evaluated using acetic acid-induced writhing, carrageennan-induced rat paw edema and Brewer's yeast-induced pyrexia models, respectively. The extract was administered at doses of 50 and $100 \mathrm{mg} / \mathrm{kg}$. Aspirin (300 mg/kg, p.o.) was used as a reference drug in all models. Normal saline $(10 \mathrm{~mL} / \mathrm{kg}$ p.o.) was used as negative control.

Results: Phytochemical screening results indicate the presence of cardioactive glycosides, tannins, flavonoids and saponins. In the acetic acid-induced writhing model, the methanol extract exhibited significant $(p<0.05)$ analgesic effect with $58.98 \%$ reduction in writhing response at a dose of 100 $\mathrm{mg} / \mathrm{kg}$, compared with untreated control group. The extract significantly $(p<0.05)$ reduced carrageenan-induced edema at doses of 50 and $100 \mathrm{mg} / \mathrm{kg}$ to 36.84 and $47.36 \%$, respectively, after 1 $h$ of extract administration. The extract exhibited predominantly dose-dependent antipyretic effect in Brewer's yeast-induced pyrexia model. Maximum reduction in body temperature to 37.07 and $38.29^{\circ} \mathrm{C}$ at doses of 50 and $100 \mathrm{mg} / \mathrm{kg}$, respectively, was observed, compared with untreated group $\left(38.90^{\circ} \mathrm{C}\right)$ after $1 \mathrm{~h}$, but this was not significant $(p<0.05)$.

Conclusion: The plant extract exerts inhibitory effect on peripheral pain stimuli, edema and dosedependent anti-pyrexia, and thus justifies the ethnomedicinal use of Acacia jacquemontii Benth. in the management of pain, fever and inflammation.
\end{abstract}

Keywords: Acacia jacquemontii, Antipyretic, Analgesic, Anti-inflammatory

Tropical Journal of Pharmaceutical Research is indexed by Science Citation Index (SciSearch), Scopus, International Pharmaceutical Abstract, Chemical Abstracts, Embase, Index Copernicus, EBSCO, African Index Medicus, JournalSeek, Journal Citation Reports/Science Edition, Directory of Open Access Journals (DOAJ), African Journal Online, Bioline International, Open-J-Gate and Pharmacy Abstracts

\section{INTRODUCTION}

The genus Acacia (Fabaceae) is comprised of almost 1380 species. A majority of these are native to Australia and rest belongs to tropical and subtropical parts of the world [1]. Acacia jacquemontii Benth. (Fabaceae), known as Banolii (Hindi) and Chhoti kikrii (Urdu) is native to
"Thar desert" of Indo-Pak subcontinent. It is an erect shrub with multiple branches coming from below ground [2]. Traditionally, the decoction of the plant bark is used to combat fever, muscular pain and cough [3]. Many species of Acacia are reported to possess antipyretic, analgesic as well as anti-inflammatory activities when tested in different animal models. Acacia nilotica has been 
reported to exert significant $(p>0.05)$ analgesic affects in rats at dose levels of 150 and 300 $\mathrm{mg} / \mathrm{kg}$ when subjected to acetic acid-induced writhing model [4]. Eldeen et al reported the selective and weak inhibition of cyclooxygenase1 and cyclooxygenase-2 caused by the ethyl acetate bark extract of Acacia nilotica, respectively with corresponding inhibitory concentration $\left(\mathrm{IC}_{50}\right)$ values of 28 and $210 \mu \mathrm{M}$ [5]. In another study, antipyretic and analgesic effects of aqueous root extract of Acacia nilotica at dose of 100,200 and $400 \mathrm{mg} / \mathrm{kg}$ were evaluated by Brewer's yeast-induced pyrexia test in animal models. The extract at the dose 400 $\mathrm{mg} / \mathrm{kg}$ was found to decrease the rectal temperature from $39.00 \pm 0.25{ }^{\circ} \mathrm{C}$ to $37.70{ }^{\circ} \mathrm{C} \pm$ $0.15^{\circ} \mathrm{C}$ after $23 \mathrm{~h}$ of administration of extract [6]. To the best of our knowledge, this is the first report of analgesic, antipyretic and antiinflammatory activities of Acacia jacquemontii Benth. In this animal model study, the plant extract was investigated for its analgesic, antipyretic and anti-inflammatory potential in order to validate its different traditional uses.

\section{EXPERIMENTAL}

\section{Collection and extraction of plant material}

Whole plant of Acacia jacquemontii, was collected from periphery of Muzaffarghar power plant, Muzaffarghar, Pakistan in the month of July 2015. The plant material was identified by plant taxonomist, Professor Dr Altaf Ahmad Dasti (Department of Botany, Bahauddin Zakariya University, Multan, Pakistan) as Acacia jacquemontii Benth. (Fabaceae). A voucher specimen (no. 381FOC) was deposited in the herbarium of the department for future reference. The root bark was separated from the underground parts of the collected plant, chopped into small pieces and dried at room temperature for 15 days. The dried material was powdered and $400 \mathrm{~g}$ of the powder was macerated in methanol and filtered; the filtrate was concentrated under vacuum using a rotary evaporator to obtain methanol extract (AJRBM, 22g).

\section{Phytochemical screening}

Standard preliminary phytochemical screening tests were used for detection of various secondary metabolites in the extract. Briefly, Borntrager's test was used to detect anthraquinones, $\mathrm{FeCl}_{3}$ test for tannins, Dragendorff's test for alkaloids, Keller-Kiliani test for cardioactive glycosides, froth test for saponins and alkaline reagent test for confirmation of presence of flavonoids [7].

\section{Animals}

The local breed of white albino mice's weighing in the range of $20-26 \mathrm{~g}$, of any sex was used in the experiment. The animals were housed in steel cages (10 per cage) with $8 \mathrm{am}$ to $8 \mathrm{pm}$ light-dark cycle. Free access to food and water under prescribed environmental conditions was ensured. The animal studies were performed in compliance with protocols and the policies approved by the Institutional Animal Ethical Committee of Department of Pharmacy, Bahauddin Zakariya University, Multan, Pakistan (ref no: IAEC/Approval/07/2016/Pharm). Handling of the animals was carried out as per international guidelines for handling and care of experimental animals [8].

\section{Evaluation of analgesic activity}

Analgesic effect was evaluated using acetic acidinduced abdominal writhing, the animals used were white albino mice, divided in four groups $(n=6)$. Group 1 (Negative control) was administered normal saline at dosage of 10 $\mathrm{mL} / \mathrm{kg}$. Group II (Positive control) treated by aspirin at dose of $300 \mathrm{mg} / \mathrm{kg}$. Group III, IV were administered extract AJRBM at dose range of 50 $\mathrm{mg} / \mathrm{kg}$ and $100 \mathrm{mg} / \mathrm{kg}$, respectively. All the animals were administered $1 \mathrm{~mL}(0.6 \%)$ acetic acid i.p. (intraperitonially) after $1 \mathrm{~h}$ of treatment. Total number of writhing was recorded for duration of $20 \mathrm{~min}$ after $10 \mathrm{~min}$ of acetic acid injection [9].

\section{Determination of antipyretic activity}

In order to evaluate the antipyretic potential of the plant extract, Brewer's yeast-induced pyrexia test was employed. White albino mice were divided in four groups each containing six. $20 \%$ suspension of Brewer's yeast was injected subcutaneously at concentration of $10 \mathrm{~mL} / \mathrm{kg}$. Measurement of initial rectal temperature was done after eighteen hours of injection. A digital thermometer was used for this purpose. AJRBM was orally administered (50 and $100 \mathrm{mg} / \mathrm{kg}$ to respective groups). Temperature was recorded at 1st, 3rd, 5th and 6th hour after administration of drug. Aspirin was used as reference drug at a dose of $300 \mathrm{mg} / \mathrm{kg}$, p.o. [10].

\section{Evaluation of anti-inflammatory activity}

Carrageenan-induced paw edema assay was used to study the anti-inflammatory action of extract. The mice were divided randomly to four groups $(n=6)$. Normal saline was administered to 1st group $(10 \mathrm{~mL} / \mathrm{kg})$. Group 2 was administered Aspirin (300 mg/kg) intraperitoneally. AJRBM 
was received by test groups (3rd and 4th group) at dose of 50 and $100 \mathrm{mg} / \mathrm{kg}$, p.o., respectively. All the doses were administered to animals 30 minutes before the induction of edema. Sucutaneous injection $(0.5 \mathrm{ml})$ of $1 \% \mathrm{w} / \mathrm{v}$ of carrageenan was administered to each animal. Plethysmometer (Ugo Basile, Italy) was used to measure the paw volume in all groups at 1st, 3rd and 5th hour after the administration of carrageenan [11].

\section{Statistical analysis}

All the results are expressed as mean \pm SEM ( $n$ $=6$ ). Student's t-test was used to analyse data between groups while analysis of variance (ANOVA) was used to analyse analgesic, antipyretic and anti-inflammatory data among groups, followed by Dunnet's test for multiple comparisons. $P<0.05$ was taken as statistically significant. The software used was SPSS, version 24 (IBM).

\section{RESULTS}

\section{Phytochemical profile}

The phytochemical profile of the plant extract is summarised in Table 1.

Table 1: Phytochemical profile of Acacia jacquemontii Benth. extract

\begin{tabular}{ll}
\hline Secondary metabolites & Result \\
\hline Alkaloids & Absent \\
Anthraquinones & Absent \\
Tannins & Present \\
Cardioactive glycosides & Present \\
Saponins & Present \\
Flavonoids & Present \\
\hline
\end{tabular}

\section{Analgesic activity}

The methanol extract of root bark of Acacia jacquemontii Benth. exhibited significant analgesic activity at $100 \mathrm{mg} / \mathrm{kg}$ dose. When compared with group receiving saline, the methanol extract reduced the acetic acid induced abdominal constrictions by $58.98 \%$ at $100 \mathrm{mg} / \mathrm{kg}$ dose $(p<0.05)$ (Table 2$)$. Inhibition of writhing response was predominantly reduced more or less in dose dependent manner.

\section{Anti-inflammatory activity}

The results of the carrageenan-induced paw edema of Acacia jacquemontii are presented in Table 3. The Acacia jacquemontii root bark extract demonstrated significant $(p<0.05)$ antiinflammatory activity at test doses of 50 and 100 $\mathrm{mg} / \mathrm{kg}$ after $1 \mathrm{~h}$ of drug administration. The Acacia jacquemontii Benth. root bark extract exhibited $36.84 \%$ and $47.36 \%$ protection against inflammation after $1 \mathrm{~h}$ of drug administration at the dose of 50 and $100 \mathrm{mg} / \mathrm{kg}$ body weight, respectively.

\section{Antipyretic activity}

The results of antipyretic activity in brewer's yeast-induced pyrexia model are summarized in Table 4. A highly significant $(p<0.01)$ antipyretic effect of plant extract was observed with dose of $100 \mathrm{mg} / \mathrm{kg}$ at $1 \mathrm{~h}$ interval following extract administration. The dose of $50 \mathrm{mg} / \mathrm{kg}$ of the extract produced significant reduction of rectal temperature at $1 \mathrm{~h}$ interval. However, a predominant dose dependent response in rectal temperature depression was evident from the results.

Table 2: Analgesic activity (acetic acid-induced writhing) of Acacia jacquemontii extract

\begin{tabular}{llcccc}
\hline Group & Treatment & Dose & $\begin{array}{c}\text { Route of } \\
\text { administration }\end{array}$ & No. of writhes & $\begin{array}{c}\text { Inhibition of } \\
\text { writhing } \\
\text { response (\%) }\end{array}$ \\
\hline I & Control & $10 \mathrm{~mL} / \mathrm{kg}$ & Oral & $47.91 \pm 3.68$ & 0 \\
II & Aspirin & $300 \mathrm{mg} / \mathrm{kg}$ & i.p. & $9.74 \pm 2.39$ & $79.67^{* *}$ \\
III & AJRBM & $50 \mathrm{mg} / \mathrm{kg}$ & i.p. & $32.97 \pm 1.78$ & 31.18 \\
IV & AJRBM & $100 \mathrm{mg} / \mathrm{kg}$ & i.p. & $19.65 \pm 1.99$ & $58.98^{*}$ \\
\hline \multicolumn{2}{l}{ Mean \pm SEM $(n=6) ;{ }^{*} p<0.05$ (significant); ${ }^{* *} p<0.01$ (highly significant) } &
\end{tabular}

Table 3: Anti-inflammatory activity of Acacia jacquemontii extract

\begin{tabular}{|c|c|c|c|c|c|c|c|}
\hline \multirow{2}{*}{ Group } & \multirow{2}{*}{ Dose } & \multicolumn{3}{|c|}{ Paw volume increase (mL) } & \multicolumn{3}{|c|}{ Inhibition (\%) } \\
\hline & & $1 \mathrm{~h}$ & $3 \mathrm{~h}$ & $5 \mathrm{~h}$ & $1 \mathrm{~h}$ & $3 \mathrm{~h}$ & $5 \mathrm{~h}$ \\
\hline Control & $10 \mathrm{ml} / \mathrm{kg}$ & $0.38 \pm 0.09$ & $0.67 \pm 0.04$ & $0.85 \pm 0.04$ & - & - & - \\
\hline Aspirin & $300 \mathrm{mg} / \mathrm{kg}$ & $0.12 \pm 0.01^{* *}$ & $0.23 \pm 0.01^{* *}$ & $0.29 \pm 0.02^{* *}$ & 68.42 & 65.67 & 65.88 \\
\hline AJRBM & $50 \mathrm{mg} / \mathrm{kg}$ & $0.24 \pm 0.03^{*}$ & $0.44 \pm 0.02 *$ & $0.57 \pm 0.03^{*}$ & 36.84 & 34.32 & 32.94 \\
\hline AJRBM & $100 \mathrm{mg} / \mathrm{kg}$ & $0.20 \pm 0.04^{*}$ & $0.38 \pm 0.02^{*}$ & $0.49 \pm 0.03^{*}$ & 47.36 & 43.28 & 42.35 \\
\hline
\end{tabular}


Table 4: Antipyretic activity (Brewer's yeast-induced pyrexia) of Acacia jacquemontii extract

\begin{tabular}{cccccccc}
\hline \multirow{2}{*}{ Group } & \multirow{2}{*}{ Dose } & \multicolumn{7}{c}{ Rectal temperature in ${ }^{\mathbf{}} \mathbf{C}$} \\
\cline { 2 - 8 } & & $\mathbf{1 8}^{\mathbf{a}} \mathbf{h}$ & $\mathbf{0}^{\mathbf{b}} \mathbf{h}$ & $\mathbf{1 ~ h}$ & $\mathbf{3} \mathbf{h}$ & $\mathbf{5 ~ h}$ & $\mathbf{6} \mathbf{h}$ \\
\hline Control & $10 \mathrm{ml} / \mathrm{kg}$ & $37.62 \pm 0.29$ & $38.22 \pm 0.02$ & $38.90 \pm 0.13$ & $38.74 \pm 0.11$ & $38.62 \pm 0.05$ & $38.81 \pm 0.03$ \\
Aspirin & $300 \mathrm{mg} / \mathrm{kg}$ & $37.45 \pm 0.26$ & $38.30 \pm 0.11^{* *}$ & $36.26 \pm 0.11^{* *}$ & $35.10 \pm 0.06^{* *}$ & $34.01 \pm 0.12^{* *}$ & $35.01 \pm 0.22^{* *}$ \\
AJRBM & $50 \mathrm{mg} / \mathrm{kg}$ & $37.11 \pm 0.14$ & $38.39 \pm 0.14^{\text {ns }}$ & $38.29 \pm 0.13^{*}$ & $38.28 \pm 0.24^{\mathrm{ns}}$ & $37.62 \pm 0.19 \mathrm{~ns}$ & $37.38 \pm 0.11^{\mathrm{ns}}$ \\
AJRBM & $100 \mathrm{mg} / \mathrm{kg}$ & $37.23 \pm 0.16$ & $38.59 \pm 0.10^{\text {ns }}$ & $37.07 \pm 0.11^{* *}$ & $37.52 \pm 0.22^{\mathrm{ns}}$ & $37.59 \pm 0.12^{\text {ns }}$ & $37.20 \pm 0.13^{\text {ns }}$ \\
\hline
\end{tabular}

Mean $\pm \operatorname{SEM}(n=6) ; n . s=$ not significant; ${ }^{*}=p<0.05$ (significant); ${ }^{* *}=p<0.01$ (highly significant), $a=$ temperature just before yeast injection; $b=$ temperature just before drug administration

\section{DISCUSSION}

Inflammation, pain and pyrexia underlie various pathological conditions. Synthetic drugs, i.e. NSAID, opioids and corticosteroids are clinically most important drugs which are being used to treat various inflammatory disorders, however there may be occurrence of adverse effects as a result of their long term use such as gastrointestinal ulcers, bleeding, renal disorders, dependence etc. [12,13]. Worldwide efforts are being made to launch medicinal plants research in order to build up novel, valuable, cost-effective and safe drugs. It is evident that medicinal plants are an important source of useful medicinal compounds offering a variety of potential therapeutic effects [14].

The results have shown that the root bark methanol extract of Acacia jacquemontii Benth. possesses significant analgesic, antiinflammatory and antipyretic activity. Carrageenan induced paw edema is widely used experimental model to study out the acute inflammatory response. The progress of edema induction consists of two phases: The "early phase" (up to $1 \mathrm{~h}$ ) involves release of histamine and serotonin. "Second phase" (more than $1 \mathrm{~h}$ ) is characterized by release of kinins as well as discharge of various products of cyclooxygenases. It may be assumed that the anti-inflammatory potential of plant extract may be correlated partly with inhibition of inflammatory mediator release and partly because of inhibitory effects on migration and accumulation of neutrophils and macrophages at the area of inflammation as test extract showed inhibition at 1-5 $\mathrm{h}$ of administration in both phases of edema development. The analgesic potential of extract was studied by using acetic acid induced writhing model that is type of "visceral pain model". The significant analgesic effect exhibited by the plant extract is believed to be a result of decreased release of arachidonic acid. However, the contribution of antiinflammatory activity of the test extract towards analgesic outcome cannot be ruled out [15]. Consequently, it is assumed that the antiinflammatory effect of extract contributed as well to its analgesic effect. Brewer's yeast induced pyrexia assay exhibited that the plant extract have shown a predominant dose dependent antipyretic effect at $1 \mathrm{~h}$ after hyperpyrexia.

Preliminary phytochemical investigation indicated the presence of cardiotonic glycosides, tanins, flavonoids as well as saponins. Flavonoids are known to possess the ability to inhibit both the cyclooxygenase and 5-lipoxygenase pathways [16]. This inhibitory effect leads to reduction of arachidonic acid release. The arachidonic acid is the precursor of inflammatory mediators such as prostaglandins and leukotrienes [17]. Saponins have been known to possess a good antiinflammatory activity by inhibiting enzyme phospholipase A2, cyclooxegenase-2, cytokines and chemokines. Quercetin, a well-known flavonoid, in particular inhibits both cyclooxygenase and lipoxygenase activities, which results in reduced formation of inflammatory mediators [18]. Hence, it may be concluded that the flavonoids and saponins present in the extract might have contributed to its analgesic, anti-inflammatory as well as antipyretic activity.

\section{CONCLUSION}

The findings of this study show that the methanol extract of Acacia jacquemontii Benth. possesses significant analgesic, anti-inflammatory and antipyretic effect, thus lending credence to its traditional use in the management of fever, pain and inflammatory conditions. The presence of flavonoids and saponins in plant extract may possibly account for these activities which are likely mediated by means of its inhibitory effect on the production and release of a variety of autacoids. The isolation of biologically active compounds responsible for the observed effects is under way in our laboratory.

\section{DECLARATIONS}

\section{Acknowledgement}

The authors are grateful to the Department of Pharmacy, Bahauddin Zakariya University, 
Multan, Pakistan for providing research facilities for this study.

\section{Conflict of Interest}

No conflict of interest associated with this work.

\section{Contribution of Authors}

The authors declare that this work was done by the authors named in this article and all liabilities pertaining to claims relating to the content of this article will be borne by them.

\section{REFERENCES}

1. Maslin BR, Miller JT, Seigler DS. Overview of the generic status of Acacia (Leguminosae: Mimosoideae). Australian Sys Bot 2003; 16(1): 1-8.

2. Choudhary $K$, Singh M, Shekhawat NS. Ethnobotany of Acacia jacquemontii Benth.-An Uncharted Tree of Thar Desert, Rajasthan, India. Ethnobotanical Leaflets 2009; 2009(6): 1.

3. Shaheen $H$, Qureshi R, Akram A, Gulfraz M. Some important medicinal flora of Noorpur Thal, Khushab, Pakistan. Arch Des Sci 2012; 65(2): 57-73.

4. Rather LJ, Mohammad F. Acacia nilotica (L.): a review of its traditional uses, phytochemistry, and pharmacology. Sustainable Chem Pharm 2015; 2: 12-30.

5. Eldeen IM, Van Heerden FR, Van Staden J. In vitro biological activities of niloticane, a new bioactive cassane diterpene from the bark of Acacia nilotica subsp. kraussiana. J Ethnopharmacol 2010; 128(3): 555-560.

6. Alli LA, Nafiu MO, Adesokan AA, Akanji MA, Tijani AY, Salawu QA. Antipyretic and analgesic activities of aqueous extract of Acacia nilotica root. Biokem 2015; 26(2): 55-62.

7. Brain KR, Turner TD. The practical evaluation of phytopharmaceuticals. Bristol: Wright-Scientechnica; 1975.
8. Care A, Use Committee. Guidelines for the capture, handling, and care of mammals as approved by the American Society of Mammalogists. J Mammal. 1998; 1:1416-31.

9. Kang JY, Khan MN, Park NH, Cho JY, Lee MC, Fujii $H$, Hong YK. Antipyretic, analgesic, and anti-inflammatory activities of the seaweed Sargassum fulvellum and Sargassum thunbergii in mice. J Ethnopharmacol 2008; 116(1): 187-190.

10. Khan $H$, Saeed M, Gilani AH, Muhammad N, Haq IU, Ashraf N, Rehman NU, Haleemi A. Antipyretic and anticonvulsant activity of Polygonatum verticillatum: comparison of rhizomes and aerial parts. Phytother Res 2013; 27(3): 468-471.

11. Bukhari IA, Khan RA, Gilani AH, Ahmed S, Saeed SA. Analgesic, anti-inflammatory and anti-platelet activities of the methanolic extract of Acacia modesta leaves. Inflammopharmacol 2010; 18(4): 187-196.

12. Griffin MR. Epidemiology of nonsteroidal antiinflammatory drug-associated gastrointestinal injury. The American J Med 1998; 104(3): 23S-29S.

13. Cryer B, Duboisø $A$. The advent of highly selective inhibitors of cyclooxygenase a review. Prostaglandins \& other lipid mediators. 1998; 56(5): 341-361.

14. Vane JR, Botting RM. New insights into the mode of action of anti-inflammatory drugs. Inflam Res 1995; 44(1): 1-10.

15. Franzotti $E M$, Santos $C V$, Rodrigues $H M$, Mourao $R H$, Andrade MR, Antoniolli AR. Anti-inflammatory, analgesic activity and acute toxicity of Sida cordifolia L.(Malvabranca). J Ethnopharmacol 2000; 72(1): 273-277.

16. Ferrandiz ML, Nair AG, Alcaraz MJ. Inhibition of sheep platelet arachidonate metabolism by flavonoids from Spanish and Indian medicinal herbs. Die Pharm 1990; 45(3): 206-208.

17. Hussain SN, Chaudhry BA, Uzair M, Qaisar MN. Studies on the analgesic and anti-inflammatory effects of Cassia sophera roots. A P J T D 2015; 5(6): 483-488.

18. Miyazawa M, Okuno $Y$, Fukuyama M, Nakamura SI, Kosaka H. Antimutagenic activity of polymethoxyflavonoids from Citrus aurantium. J Agri Food Chem 1999; 47(12): 5239-5244. 